\title{
Geometric Transformation in Surakarta Batik Patterns
}

\author{
Melindawati Kusuma Anggraen \\ Universitas Sebelas Maret \\ Surakarta, Indonesia \\ melindawatikusuma@student.uns.ac.id
}

\author{
Mardiyana \\ Universitas Sebelas Maret \\ Surakarta, Indonesia \\ mardiyana@ staff.uns.ac.id
}

\author{
Dewi Retno Sari Saputro \\ Universitas Sebelas Maret \\ Surakarta, Indonesia \\ dewiretnoss@staff.uns.ac.id
}

\begin{abstract}
Ethnomatematics is mathematics that grows and develops in a society. Batik Surakarta is one of the cultural wealth in Indonesia that has the potential to increase the knowledge of society about the concept of mathematics, especially the geometric transformation. Surakarta batik patterns are influenced by the culture of the palace, at first the patter is formed from meaningful symbols that nuanced traditional Javanese, Islamic, Hinduism and Buddhism. As a descriptive qualitative study, this study aims to describe the mathematical concepts contained in Surakarta batik patterns. The mathematical concept in this study focused on the geometric transformation. The application of geometric transformation such as reflection to form the same batik patterns to coexist so as to form a unity of new motifs intact, translation to reproduce patterns of the same height and width so as to form a sequence or series of uniform motifs, while rotation can form the motive in reverse and dilatation can form a motif with different magnification. In addition to the four concepts of geometric transformation, there is also the application of the transformation of batik in Surakarta. Thus, there is application of geometric transformation in Surakarta batik patterns.
\end{abstract}

Keywords: $\quad$ ethnomathematics;

geometric transformation;Surakarta batik patterns.

\section{INTRODUCTION}

The results of the mathematical activities developing among the society can be seen in the cultural relics such as on cloth, inscriptions, traditional equipment, traditional games and other cultural characteristics. Batik is one of the mentioned characteristics that exists in almost all regions in Indonesia and worn by people in their daily life. Batik comes from the language of Batik that is one of the cultural heritages of Indonesia's ancestors. Indonesian batik has been officially recognized by UNESCO as an intangible cultural heritage on October $2^{\text {nd }}, 2009$ [1]. The city of Surakarta is one of the cities holding a variety of cultures. Batik is one of the cultural characteristics that cannot be separated from Surakarta. The form of batik's specialty is owned by the interior area of Surakarta, so that the batik pattern is influenced by the palace motif. When viewed carefully, it is not uncommon for the motifs of Surakarta batik to show the existence of mathematical concepts in it, especially the concept of geometry. This shows that mathematics has become part of the Surakarta community.

Mathematical concepts, especially geometry contained in cultures such as batik, have been embedded for generations.
This means that indirectly people have understood mathematics, especially the concept of geometry in the batik motifs they created. Mathematics practiced among cultural groups is identified such as national tribal communities, labour groups, children from certain age groups and professional classes called ethno-mathematics [2]. Ethno-mathematics includes mathematical ideas, thoughts and practices developed by all cultures [3]. Mathematical ideas or concepts emerge naturally through the knowledge of certain people in ancient times without going through formal education. Ethnomathematics serves to express the relationship between culture and mathematics [4]. D'Ambrosio [5] stated that the existence of ethno-mathematics is to emphasize that there are other ways of applying mathematics by the community by considering academic mathematical knowledge developed by various sectors of society and considering the culture containing mathematical practices such as how to classify, calculate, measure, building buildings or traditional tools and games.

It is clear and visible how the concept of geometry is in the motif of Surakarta batik in the form of points, lines and flat fields. These flat fields are for example circles, ellipses, rectangles and the like. Another concept of geometry that is applied to form a Surakarta batik motif is transformation geometry. According to Iswahyudi [6], the artistic form of batik is produced through the transformation of dots, lines or flat fields on batik through translation (shift), rotation (rotation), reflection (reflection) or dilation (magnification). Based on this, the way of the transformation geometry concept is applied in the Surakarta batik motif will be described and discussed.

\section{Methodology}

This research is a qualitative research because it is oriented to phenomena or symptoms that are factual. According to Sutama [7], qualitative research puts more emphasis on understanding and meaning, closely related to certain values. Judging from the data presentation techniques, the research uses descriptive patterns. Descriptive pattern according to Best in Sukardi [8] is a research method that attempts to describe and interpret objects as they are. This descriptive study is not intended to test certain hypotheses, but only illustrates what it is about the application of transformation geometry on the Surakarta batik motif. The data source in this study is batik cloth found in the "Danar Hadi" Ancient Batik Museum in Surakarta. 


\section{Prepare Your PAPER BEFore StYLing}

\section{A. Geometric Transformation}

Transformation geometry is part of geometry which talks about transformation (change), both the change in location and presentation based on images and matrices. The concept of transformation provides background knowledge to develop new perspectives in visualization skills [9]. Transformation geometry has several types, namely translation, rotation, reflection and dilatation. Shift or translation is a transformation in the form of moving points, lines, or fields with a certain distance and direction. Reflection is a type of transformation that uses the shadow properties of a mirror in its displacement. Rotation is the displacement of points, lines or fields as far as $\theta$ from a particular centre point. Dilation is multiplication of points, lines, or fields with a certain multiplier factor.

Shirley [10] holds that today the field of ethnomatematics, which is mathematics that grows and develops in society and is in accordance with local culture, can be used as a centre of learning processes and teaching methods, although it is still relatively new in the world of education. Indonesian culture such as batik can be used by teachers to help students understand the concept of geometric transformation. Students need to concrete opportunities to supplement the words and visuals that are represented in transformational geometry [11].

\section{B. Application of Translation (Shift) in Surakarta Batik Patterns}

The motifs of Surakarta batik contain the concept of transformation geometry, one of which will be explained is the concept of translation. The definition of translation specifies that the point of the object is moved in the same direction [12]. While Usisk in et al. [13] mentions that geometric translation "the sliding of an object from one to another place without changing its orientation." the translation is the simplest of the transformations, sometimes called a slide, or a shift. The translation vector can be shown by sequential numbers written in the form of a column matrix $\left(\begin{array}{l}a \\ b\end{array}\right)$ a translation of $\mathrm{T}$ with the translation vector $\left(\begin{array}{l}a \\ b\end{array}\right)$ transforms the point $\mathrm{P}$ to $\mathrm{P}$ ', mapping can be written as $p(x, y) \stackrel{T=\left(\begin{array}{l}a \\ b\end{array}\right)}{\longrightarrow} P^{\prime}(x+a, y+b)$. If $P^{\prime}\left(x^{\prime}, y^{\prime}\right)$, relations can be written algebraically $x^{\prime}=x+a, y^{\prime}=y+b$. Point $\mathrm{P}$ 'is called the shadow point $\mathrm{P}$ by translation $T=\left(\begin{array}{l}a \\ b\end{array}\right)$. The following will show the Surakarta batik pattern which has the concept of translation.

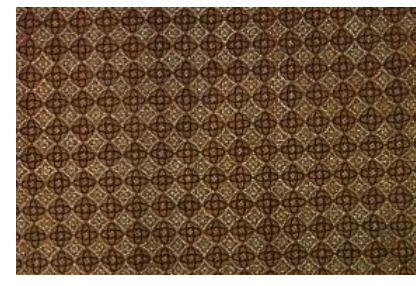

Figure 1. Pattern 1

Translation of the motif is marked by moving or shifting the initial motive to a certain position with the same direction and distance. Figure 1 can be referred to as the result of a shift with the process as the following

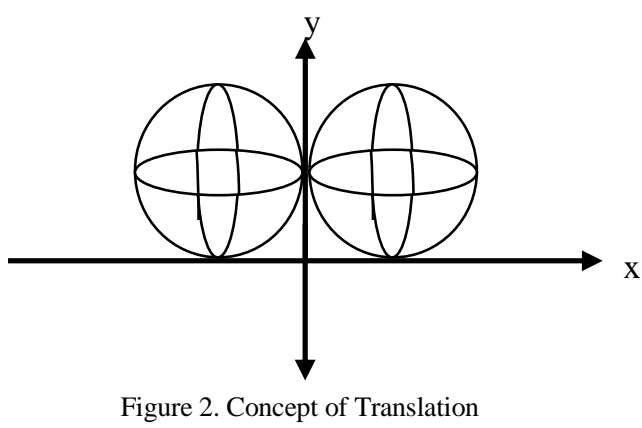

Initial motives can be processed through vertical shifts and can also be processed through horizontal shifts to be produced as shown in figure 1.

\section{Application of reflection in Surakarta batik pattern}

The reflection of a geometrical construct is the process of reflecting each point of building the geometry against a predetermined line. The line is called the mirror axis or symmetry axis. If a geometry build is reflected on a particular line, then the reflection build or called the shadow must be congruent with the initial wake.



Figure 3. Pattern 2

The concept of reflection is also found in the making of Surakarta batik motifs. For example, as shown in Figure 3 forming was done by making the initial motif then reflected on the $y$ axis

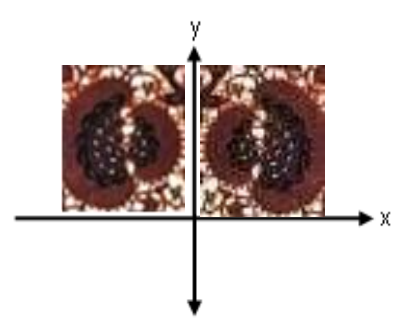

Figure 4. Concept of Reflection

Figure 4 is a reflection concept found in Surakarta batik patterns thrnow the v axis with the following conditions::

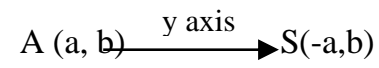

\section{Application of rotation on Surakarta batik pattern}

The concept of rotation is also found in making of Surakarta batik motifs. The concept of rotation is to rotate the motif according to its axis. Rotation can be interpreted as a transformation that moves a point on a plane with a certain angle where the clockwise angle is negative and the counter-clockwise angle is positive. A rotation with centre $\mathrm{P}$ and rotation angle rotation $\theta$ is 
written R $(\mathrm{P}, \theta)$. If $R(P, \theta):(x, y) \rightarrow\left(x^{\prime}, y^{\prime}\right)$ with $\mathrm{P}(\mathrm{a}, \mathrm{b})$, there is relation as follows:

$x^{\prime}=(x-a) \cos \theta-(y-b) \sin \theta+a$

$y^{\prime}=(x-a) \sin \theta+(y-b) \cos \theta+b$.

The following will show the Surakarta batik pattern which has the concept of rotation.

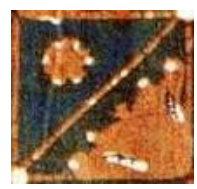

Figure 5. Initial Pattern

The initial motive rotated by $90^{\circ}$ will produce the following motives;



Figure 6. Concept of Rotation

The initial motive is then arranged horizontally with a rotation motive so as to produce new motives as follows;

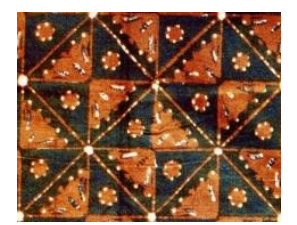

Figure 7. Pattern 3

\section{E. Application of dilatation in Surakarta batik pattern}

In addition to translation, reflection and rotation, Surakarta batik motif also contains the concept of dilatation. Dilation is a transformation that either reduces or enlarges a figure. Dilation stretches or shrinks the original figure and alters the size of the pre image. Hence, it is not rigid because it does not satisfy the condition of the image which is congruent to the pre image [12]. Dilation can also be interpreted as a factor that causes an enlarged or minimized build up. A dilated by scale factor $\mathrm{k}$ and centre dilatation $\mathrm{P}$ is written $[\mathrm{P}, \mathrm{k}]$. If $[P, k]: A(x, y) \rightarrow$ $A^{\prime}\left(x^{\prime}, y^{\prime}\right)$ with $P(a, b)$, there is relation as $x^{\prime}=a+k(x-a)$ and $y^{\prime}=b+k(y-b)$. The following will show the Surakarta batik pattern which has the concept of dilatation.



Figure 8. Pattern 4

The following is the dilatation concept as shown in figure 8;

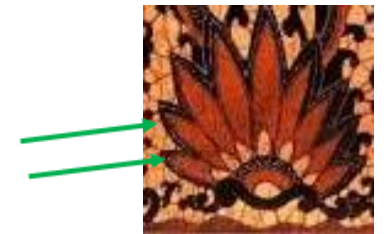

Figure 9. Concept of Dilatation

From figure 9 it can be seen that the dilatation concept is found in one of Surakarta batik motifs. The dilatation concept is marked with the same image but with different sizes.

\section{CONCLUSION}

Transformation geometry is a part of geometry which talks about transformation (change), both the change in location and presentation based on images and matrices. The motifs of Surakarta batik do not only contain elements of Javanese culture, but also elements of mathematics. The mathematical elements found in the motif of Surakarta batik is the concept of transformation geometry in the form of translation (shift), rotation, reflection and dilation (magnification). The application of geometric transformation such as reflection to form the same batik patterns to coexist so as to form a unity of new motifs intact, translation to reproduce patterns of the same height and width so as to form a sequence or series of uniform motifs, while rotation can form the motive in reverse and dilatation can form a motif with different magnification.

\section{REFERENCES}

[1] Windria, Hening. (2016). Batik Kaya Matematika. Prosiding Seminar Nasional Pendidikan Matematika 2016. Malang.

[2] Gerdes, P. (1994). Reflections on mathematics. For the Learning of Mathematics, 14: 19-22.

[3] Barton, B. (1996). Ethnomathematics: Exploring cultural diversity in mathematics. New Zealand: University of Aucklan.

[4] Marsigit. (2016). Pengembangan Pembelajaran Matematika Berbasis Etnomatematika. Makalah dipresentasikan pada Seminar Nasional Matematika dan Pendidikan Matematika 2016 STKIP PGRI Sumatera Barat dengan Tema Etnomatematika, Matematika dalam Perspektif Sosial dan Budaya. Padang. Indonesia.

[5] D'Ambrosio, Ubiratan. (2004). Peace, social justice and ethnomathematics. The Montana Mathematics Enthusiast. pp 34 - 35.

[6] Iswahyudi, Gatut. (2003). Geometri Transformasi Edisi Pertama. Surakarta: UNS Press.

[7] Sutama. (2012). Metode Penelitian Pendidikan Kuantitatif, Kualitatif, PTK, R\&D. Surakarta: Fairus Media.

[8] Sukardi. (2009). Metodologi Penelitian Pendidikan: Kompetensi dan Praktiknya, Cet. 9, Jakarta: PT. Bumi Aksara.

[9] National Council of Teachers of Mathematics. (1989). Curriculum and evaluation standards for school mathematics. Reston, VA: Author.

[10] Shirley, L. (1995). Using Ethnomathematics to Find Multicultural Mathematical Connection: NCTM.

[11] Martinie, S., \& Stramel, J. (2004). Manipulatives in the middle school. Mathematics Teaching in the Middle School, 9(6), 332-3.

[12] Zorin, Barbara. (2011). Geometric Transformations in Middle School Mathematics Textbooks. Graduate These and Dissertations. http://scholarcommons.usf.edu/etd/3421.

[13] Usiskin, Zalmon, Anthony L. Peressini, Elena A. Marchisotto, and Dick Stanley. (2003). Mathematics for High School Teachers: An Advanced Perspective. Upper Saddle River, NJ: Pearson Education. 